\title{
Radial variation in selected wood properties of three cypress taxa
}

\author{
Christine L. Todoroki ${ }^{1}$, Charlie B. Low ${ }^{1 *}$, Heather M. McKenzie ${ }^{2}$ and Luis D. Gea ${ }^{3}$
}

\begin{abstract}
Background: New Zealand-grown cypresses are typically harvested at 35-40 years of age; however, shorter rotations have been proposed. The objective of this study was to evaluate the feasibility of producing structural products from shorter rotations through examination of wood properties of younger cypress trees. A detailed examination of radial wood property trends was necessary, and the first ring-level models for three cypress taxa were developed because there were no predictive wood property models available.

Methods: Radial trends in wood density, microfibril angle (MFA) and modulus of elasticity (MOE) were examined for 55 trees of three taxa (Cupressus lusitanica Mill, C. macrocarpa Gordon and Chamaecyparis nootkatensis (D.Don) Spach $\times$ Cupressus macrocarpa). The trees, planted in row-plots, were harvested at age 21 years at which time breast-height increment cores were extracted to determine wood properties. Rings 1 through 18 were examined in detail and used as the basis for developing mixed-effects ring-level models.
\end{abstract}

Results: Taxon, cambial age, ring width and aspect were highly significant as explanatory variables in wood-density models. Trees with a northern aspect (the warmest side with most sunlight) had greater density than those at the south of the plot. Trees with a southern aspect (least sunlight) had significantly lower MOE, which was about 1-2 GPa below the average of 11-13 GPa at age 18 years. Aspect, however, was not significant in models for MFA. Microfibril angle of the cupressus hybrid declined from about $30^{\circ}$ at the pith to $13^{\circ}$ near the bark, whereas for Cupressus lusitanica, the range was about $36-16^{\circ}$ and about $31-16^{\circ}$ for Cupressus macrocarpa.

Conclusions: The results of this study provide a basis for determining management strategies appropriate to structural timber production from cypress stands. Overall, forecasted ages for production of strength-grade timber were least for the cupressus hybrid. In an application of the models, products of $6 \mathrm{GPa}$ could be obtained from the outer zones of trees of the hybrid from age 22 years and at older ages for the other taxa. Shorter rotations would, therefore, be feasible for the hybrid taxon.

Keywords: Density, Microfibril angle, Modulus of elasticity, Radial variation, Cypress, Mixed-effects models

\section{Background}

Cypress timber is known for its stability, attractive grain and natural durability. In comparison with other species, it has a relatively steady wood-density gradient (Brailsford 1999). The timber is commonly used for wall panelling, flooring, architraves, skirting, furniture and interior joinery. It has also been reported as suitable for a wide range of exterior uses, including exterior joinery, weatherboards and boat building, and is an approved building species (Haslett 1986). Timber from New Zealand-grown cypresses

\footnotetext{
* Correspondence: Charlie.Low@scionresearch.com

'Scion, Private Bag 3020, Rotorua 3046, New Zealand

Full list of author information is available at the end of the article
}

is produced from trees that are typically $35-40$ years of age when harvested. However, shorter rotations of closer to 20 years have been proposed (Brailsford 1999). The objective of this study was to evaluate the feasibility of producing structural products from shorter rotations through examination of wood properties of younger cypress trees.

Wood properties of particular importance to structural products include wood density, microfibril angle (MFA) and modulus of elasticity (MOE). Wood density is an indicator of strength. Typically, air-dry wood density of New Zealand-grown cypresses ranges from 475 to 495 kg.m ${ }^{-3}$ (Miller and Knowles 1996). Microfibril angle is an indicator of stiffness and is derived from the angle

\section{实 Springer}


of cellulose strands in the thickest (S2) layer of the cell wall relative to the long axis of the tracheid (Donaldson 1987). The lower the MFA, the higher the stiffness and the more stable the timber (Yang and Evans 2003, Fang et al. 2006). Together, wood density and MFA determine MOE (Walker and Butterfield 1995, Evans and Ilic 2001, Yang and Evans 2003), a measure of stiffness and an overall indicator of strength. The characteristic bending stiffness of machine-graded pine (MGP) in New Zealand with grades of MGP 6, MGP 8 and MGP 10 is 6.0, 8.0 and $10.0 \mathrm{GPa}$, respectively, while No. 1 framing and engineering grades (both visually assessed) have minimum requirements of 8.0 and $10.5 \mathrm{GPa}$, respectively (Gaunt 1998, Standards New Zealand 1993).

The three radial wood properties (density, MFA and $\mathrm{MOE}$ ), along with ring width, can all be assessed using Silviscan technology (Innventia Ab, Stockholm, Sweden). Following the invention of Silviscan by Evans et al. (1995), numerous studies have used this technology for investigating within-tree wood properties of a range of species including Eucalyptus globulus Labill., E. nitens H.Deane \& Maiden and E. regnans F.Muell. (Yang and Evans 2003), Picea abies (L.) Karst. (Lundgren 2004, Piispanen et al. 2014), Pinus taeda L. (Jordan et al. 2005), Pseudotsuga menziesii (Mirb.) Franco (Vikram et al. 2011), Pinus sylvestris L. (Auty et al. 2013) and Pinus radiata D.Don (Ivković et al. 2013). To our knowledge, there have been no studies investigating within-tree radial variation of any cypress taxa.

In general, radial wood density varies with both age and ring width (Franceschini et al. 2010, Jyske et al., 2008). Ring width, in turn, is influenced by climate (Bouriaud et al., 2004; Wimmer and Downes 2003), aspect (van der Maaten 2012), silvicultural practices (Filipescu et al. 2014) and cambial age. While many different forms of models have been presented for the relationship between ring width and age (or equivalently time), the commonly used Hugershoff (1936) (cit Peschel 1938) curves (Eq. 1) have often been reported as being the most robust (Fang et al. 2010, Bošela et al. 2011).

$$
y(t)=a \times t^{b} \times e^{-c t}+d
$$

where $y(t)$ is the response variable at time, $t$, and $a, b, c$ and $d$ are parameters to be estimated.

Microfibril angle also varies with age, being higher nearer the pith and declining with increasing cambial age (McMillin 1973, Zhang et al. 2007). The relationship between MFA and cambial age has been examined in many other studies, with a comprehensive list provided by Donaldson (2008) in a review of MFA measurement, variation and relationships. Relationships with MOE, like those for density, show a general increase with cambial age (e.g. Lasserre et al. 2009, Cortini et al. 2014).
Little research effort has focussed on wood property variation within and among cypress genera. Furthermore, some contradictory results have been found among the few published studies. For example, Watt et al. (2008) studied 4-year-old Cupressus lusitanica and found diameter (measured at ground level) to be highly correlated with wood density, but Malimbwi et al. (1992) found density and diameter to be unrelated in a study of 19-year-old C. lusitanica trees. McKinley et al. (2000) studied a sample of four cypress taxa (C. lusitanica Miller, C. macrocarpa Gordon, Chamaecyparis lawsoniana (Murray) Parl. and Chamaecyparis nootkatensis (D.Don) Spach $\mathrm{x}$ Cupressus macrocarpa) ranging in age from 13 to 52 years and found wood density was unrelated to tree age. However, wood stiffness of a sample of boards sawn from 21-year-old Cupressus lusitanica trees was shown to be strongly influenced by cambial age (Low et al. 2005). The boards (all sawn from butt logs and mechanically tested) were classified as follows: Inner (when sawn from the innermost rings), Outer (when sawn from the outermost rings) and Intermediate (when sawn from intermediary positions). Mean stiffness of the Inner, Intermediate and Outer samples was 4.3, 5.4 and 7.2 GPa, respectively. Given that Low et al. (2005) also found that mean stiffness of C. lusitanica boards was less than that of either C. macrocarpa or the Chamaecyparis nootkatensis $\mathrm{x}$ Cupressus macrocarpa boards of the same age, a lowered harvesting age of less than 35 years appears plausible.

The objective of this study was to determine whether or not the wood of younger cypress trees is sufficient to meet the requirements of structural products. Firstly, relationships among wood density, MFA and MOE on core samples obtained from trees of three cypress taxa were investigated. The taxa studied were Cupressus lusitanica, C. macrocarpa and Chamaecyparis nootkatensis $\mathrm{x} C$. macrocarpa. These are referred to as Lusitanica, Macrocarpa and Leyland, respectively, from here on. Subsequently, mixed-effects models were developed to evaluate cambial age, ring width, distance from pith, edge effect and aspect as suitable candidate explanatory variables. The models were then used to predict wood properties over an extended time horizon, extrapolated beyond the data range and applied to forecast the age at which production of timber of specific dimensions and stiffness ratings would be possible.

\section{Methods}

\section{Sample Trees}

This study was conducted on a stand of cypress trees growing on pumice soil in the central North Island of New Zealand (location, 38.1 $\mathrm{S}, 176.3^{\circ}$ E, elevation $757 \mathrm{~m}$ ) where the annual rainfall is about $1350 \mathrm{~mm}$ (Chappell 2013). The stand of Leyland, Lusitanica and 
Macrocarpa was planted for demonstration purposes on the grounds of the New Zealand Forest Research Institute in 1981 (Low et al. 2005, Fig. 1). There were four Leyland hybrid clones that had been brought out as plants from England by G. W. Sturrock of the Department of Scientific and Industrial Research in the 1950s. The clones were Green Spire, Haggerston Grey, Old Alice and Clone 3. The study trees were raised from cuttings taken from these clones. Lusitanica was grown from seed collected from trees growing in Waipoua forest (location, $35.7^{\circ} \mathrm{S}, 173.6^{\circ} \mathrm{E}$; seedlot AK77/23). Macrocarpa was grown from seed collected from a shelterbelt at Bulls nursery (location, $40.1667^{\circ} \mathrm{S}, 175.3833^{\circ} \mathrm{E}$; seedlot WN77/7). Vincent and Dunstan (1989) explained seedlot numbers and systems.

A further block of 'fastigiate clone 850.020 Pinus radiata Selfs' was also planted within the stand but not used in this study. The trial was set up as a series of row-plots, where all the trees in one row were the same taxon. Rows were numbered 1 on the western side of the block and went through to 27 on the eastern side. Each row contained six trees planted along an approximate North to South axis. Trees within rows were numbered from 1 (southern aspect) to 6 (northern aspect). Intermediary trees (numbered 2 to 5 ) were categorised as having an 'interior' aspect. Being in the Southern Hemisphere, the north side is the warmest side. The cypress trees on the north side received more light following the harvest of an existing stand to the north of the cypress stand in 1998 when the study trees were about 17 years old. Those northernmost trees were also sheltered from the cold southerly (i.e. Antarctic) winds.

The stand was planted at 1111 stems per hectare and thinned to 550 stems per hectare at an age of about 10 years. Trees were also pruned to between 5 and $8 \mathrm{~m}$ depending on tree height, but details of the timing of these pruning lifts is not known. Breast-height $(1.4 \mathrm{~m})$ diameters were recorded, and breast-height increment cores were taken from 20 randomly selected trees per taxon in 2002, when the stand was 21 years old. Heights were also measured on some, but not all, trees. After elimination of cores for which ring boundaries could not be estimated, there were a total of 55 samples (20 Leyland, 19 Lusitanica and 16 Macrocarpa) available for use in this study. The location of each tree used in this study, within the row-plot design, is shown in Fig. 2.

\section{Analysis of cores using Silviscan ${ }^{\circledR}$ equipment}

The $12 \mathrm{~mm}$ cores, taken from the trees, shortly before they were felled in 2002, were sterilised by soaking in a $96 \%$ solution of ethanol then air-dried to a moisture content of $13 \%$. Due to unforeseen circumstances, there was a delay of 3 years, during which the cores were stored in plastic bags in a freezer, before shipping to Australia for analysis by Silviscan in 2005.

Cores were analysed using Silviscan ${ }^{\circledast}$ III (Evans 2006), an automated suite of instruments that provide quantitative measures of wood density by X-ray densitometry and of microfibril angle by X-ray diffraction. MOE was determined by combining the density and diffraction information as shown in Eq. 2:

$$
\mathrm{MOE}=A(I \rho)^{B}
$$

where $\rho$ is density acquired by X-ray diffraction, $I$ is the coefficient of variation of the diffraction profile (and includes scattering from the S2 layer and background scattering from S1 and S3 layers and other cell constituents) and $A$ and $B$ are species-independent calibration constants



Fig. 1 Sample of 21-year-old cypress trees in the demonstration stand 




Fig. 2 Layout of the 21-year-old cypress stand. Trees along the northern aspect (tree no. 6 in each row) received more sun and were sheltered from the cold southerly winds to which trees growing along the southern aspect (tree no. 1 in each row) were exposed

that relate to the sonic resonance method used for calibration (Evans 2006).

Density was measured at intervals of $50 \mu \mathrm{m}$, while MFA and MOE were estimated at intervals of $5 \mathrm{~mm}$ for each core. The positions of the annual ring boundaries for each core were determined from the radial density profile using software written in Interactive Data Language (IDL, proprietary software distributed by Research Systems, Inc. of Boulder, CO, USA now a division of Kodak) (http://www.ittvis.com/ProductServices/IDL.aspx) specifically for the purpose. The boundaries were manually amended where algorithms either failed to identify a boundary or found spurious boundaries. Ring averages were automatically calculated for density, MFA and MOE and the width of each ring recorded when the operator was satisfied with boundary locations. Ring width provided a point estimate of annual diameter growth information.
Less than $50 \%$ of the sample cores had 20 rings, $73 \%$ had 19 or more rings, $84 \%$ had 18 or more rings and $96 \%$ had 17 or more rings. Therefore, at 20 rings, the sample size was small and allowed for the possibility of biased samples. To examine radial patterns across as many rings as possible (while also avoiding small sample sizes) radial properties were examined here on the three cypress taxa from rings 1 to 18 inclusive. Radial properties examined were as follows: ring width, wood density, MFA and MOE.

\section{Statistical analysis}

Relationships between radial wood properties (ring width, density, MFA or MOE) and explanatory variables were developed using the linear and nonlinear mixed-effects models package, 'nlme', (Pinheiro et al., 2013) within the $R$ environment ( $R$ Core Team, 2013) with a significance level of 0.05 throughout. 
Linear models were formulated using the Laird and Ware (1982) model (Eq. 3) and developed following the protocol of Zuur et al. (2009), while nonlinear models followed the Pinheiro (2002) model (Eq. 4).

$$
\begin{aligned}
& \boldsymbol{y}=\mathbf{X} \boldsymbol{\beta}+\mathbf{Z} \boldsymbol{u}+\boldsymbol{\varepsilon} \\
& \boldsymbol{y}=f(\mathbf{X} \boldsymbol{\beta}+\mathbf{Z u})+\boldsymbol{\varepsilon}
\end{aligned}
$$

where $\mathbf{y}$ is the response vector, $\mathbf{X}$ and $\mathbf{Z}$ are matrices of explanatory variables corresponding to fixed and random effects respectively, $\boldsymbol{\beta}$ and $\boldsymbol{u}$ are the corresponding vectors of parameters for the respective fixed and random effects, $\boldsymbol{\varepsilon}$ is a vector of random errors and $f$ is a nonlinear function.

Candidate explanatory variables included (where appropriate) cambial age (i.e. ring number from pith), ring width, distance from pith, taxon, edge-tree and aspect. Interaction terms with taxon, and transformations of explanatory variables (the latter determined through inspection of graphical plots) were also modelled to address the assumption of normality. To address the assumption of homogeneity of variance, heterogeneity was incorporated into the variance structure of each model, using a power function for the ring covariate, and examined through visual plots of residuals versus fitted values. A residual autocorrelation structure, AR(1), was included in the models to address the correlated nature of the consecutive ring measurements. The variance and autocorrelation structures are described in detail by Auty et al. (2013). Random effects were modelled to allow differences due to individual tree. Selection of the most appropriate model structure was based on likelihood ratio tests and the Akaike information criterion (AIC, Akaike 1974).

Model performance was evaluated using mean absolute percentage error (MAPE, a relative measure which expresses errors as a percentage of the actual data), root mean square error (RMSE, which, although highly influenced by extreme values, is a useful measure because it assumes the same units as the response variable) and the coefficient of determination between actual and predicted data, $R^{2}$. Predictions were made at the population level, and excluded the estimated random effects, because in practice they would be unknown.

Final models for estimating density, MFA and MOE were presented with both confidence and prediction bands. Confidence intervals contained within the confidence bands indicate the likely location of the true population mean, whereas prediction intervals account for both the uncertainty in the population mean as well as data scatter. For this reason, prediction intervals are always wider than confidence intervals.

At the individual ring level, mean radial wood properties were compared using analysis of variance (ANOVA).
A one-way ANOVA was conducted to determine if differences between taxa wood properties were significant. For post-hoc testing, the Tukey honestly significant difference (HSD) test was chosen for conducting the multiple $(54=3$ (taxon) $\times 18$ (rings) $)$ pairwise comparisons. Oneway ANOVA followed by the HSD test was also conducted on the stand measurements, again using a significance level of 0.05 , to determine if there were differences between mean diameter, height and taper of the three taxa.

\section{Application of models}

It is possible to estimate the earliest age at which cypress stands might be expected to meet structural product requirements by running the radial wood property ringwidth models, the latter with consideration to tree geometry. For example, consider the production of timber, $\mathrm{W}$ mm wide $\times \mathrm{T} \mathrm{mm}$ thick $\times \mathrm{L} \mathrm{m}$ long, and of Y GPa.

To determine the minimum age at which production would be possible:

1. Use the appropriate MOE model (Leyland, Lusitanica or Macrocarpa) to determine the earliest cambial age, $A$, at which the majority of trees (i.e. lower $95 \%$ model prediction interval) would achieve Y GPa.

2. Use the ring width model to calculate the distance, $X$, from the pith to $A$ (i.e. cumulative sum of ring widths).

3. Determine the minimum radius, $R$, at a height of $\mathrm{L}+0.1 \mathrm{~m}$ (assuming a $0.1 \mathrm{~m}$ stump), $R=\left((X+T)^{2}+\right.$ $\left.(W / 2)^{2}\right)^{1 / 2}$.

4. Estimate the minimum radius at breast height $(1.4 \mathrm{~m})$ by accounting for taper, $R=R+$ taper $\times(\mathrm{L}-1.3)$, where 1.3 is breast height less stump height, and taper is the upper $95 \%$ confidence interval of taper (refer Table 1).

5. Finally, reapply the (cumulative) ring width model to estimate the expected minimum age at which $R$ is attained.

\section{Results}

\section{Mean stand characteristics of the three taxa}

On average, at age 21 years, trees of the Leyland taxon were the smallest in terms of girth (with a breast-height diameter of $334 \mathrm{~mm})$, Macrocarpa the tallest $(21.6 \mathrm{~m})$ and least tapered $\left(17.6 \mathrm{~mm} \cdot \mathrm{m}^{-1}\right)$, and Lusitanica the most tapered $\left(20.1 \mathrm{~mm} \cdot \mathrm{m}^{-1}\right)$. The Leyland and Lusitanica taxa were, on average, of similar height. Mean stand characteristics of the three taxa and sample sizes by aspect are summarised in Table 1.

\section{Measured ring width}

Mean ring width initially increased for the majority of the cypress trees, reaching a peak at a cambial age of 2 to 3 years. After peaking, ring width tended to decrease with cambial age. However, there were some fluctuations and 
Table 1 Mean stand characteristics (with $95 \%$ confidence intervals) of the three cypress taxa. Means with the same letter are not significantly different

\begin{tabular}{lllll}
\hline Taxon & Sample size $^{\mathrm{a}}$ & $\begin{array}{l}\text { Breast-height diameter } \\
(\mathrm{mm})\end{array}$ & $\begin{array}{l}\text { Total height } \\
(\mathrm{m})\end{array}$ & $\begin{array}{l}\text { Taper } \\
\left(\mathrm{mm} . \mathrm{m}^{-1}\right)\end{array}$ \\
\hline Leyland & $20(4,11,5)(13)$ & $334 \mathrm{~b}(317,352)$ & $18.3 \mathrm{~b}(17.6,19.1)$ & $17.8 \mathrm{ab}(16.3,19.3)$ \\
Lusitanica & $19(4,11,4)(19)$ & $387 \mathrm{a}(357,417)$ & $19.3 \mathrm{~b}(18.6,20.0)$ & $20.1 \mathrm{a}(18.5,19.2)$ \\
Macrocarpa & $16(4,10,2)(14)$ & $386 \mathrm{a}(350,422)$ & $21.6 \mathrm{a}(19.9,23.3)$ & $17.6 \mathrm{~b}(15.9,19.2)$ \\
\hline
\end{tabular}

${ }^{a}$ Number of trees, by aspect (north, intermediary, south) and subsample of trees for which height was measured

spikes, which were particularly pronounced for Lusitanica and Macrocarpa. Aspect appeared to have a small influence on ring width, particularly for Leyland (Fig. 3, top row) and a small thinning response was observed when the trees were aged 12 to 14 years (Fig. 3, bottom row). Subsequent to this period of thinning response, ring width again decreased with cambial age but at a slower rate than prior to the thinning response.

In years 2-8 of growth, mean ring width of Lusitanica was significantly greater than that of Leyland. Differences in mean ring width between Macrocarpa and Leyland were not significant, while differences in mean ring width between Lusitanica and Macrocarpa were significant only for rings $3(p=0.03)$ and $5(p=0.04)$. After a cambial age of 8 years, mean ring width was not significantly different between taxa.

\section{Measured wood density}

Radial trends in mean ring density were unique to each taxon with considerable variation due to individual trees (Fig. 4). The northernmost trees tended to demonstrate higher density than the southernmost trees, particularly those of the Leyland taxon (Fig. 4, top row). For Leyland, wood density declined rapidly from a mean of $570 \mathrm{~kg} . \mathrm{m}^{-3}$ at ring 1 to a mean of $470 \mathrm{~kg} \cdot \mathrm{m}^{-3}$ at ring 3 . Thereafter, mean ring density of the Leyland taxon was approximately $450 \mathrm{~kg} \cdot \mathrm{m}^{-3}$, though there was considerable variation (extending to about $\pm 100 \mathrm{~kg} \cdot \mathrm{m}^{-3}$ ) due to individual trees. For Lusitanica, mean ring density followed an approximate parabolic form for the first 10 years, with an initial density of $456 \mathrm{~kg} \cdot \mathrm{m}^{-3}$ and a minimum of $385 \mathrm{~kg} \cdot \mathrm{m}^{-3}$ at 6 years. After 10 years, mean density was relatively constant (approximately $436 \mathrm{~kg} \cdot \mathrm{m}^{-3}$ ). For Macrocarpa, mean ring density followed a relatively flat gradient, with a slight trough in the first 3 years and a slight ridge at 11 years.

The Tukey HSD test indicated significant differences among taxon means within the first 13 years of growth. Mean ring density of Lusitanica was significantly less than that of Leyland (until ring 10) and of Macrocarpa (until ring 13). Mean ring density is indicated by grey dots superimposed on the box plots in Fig. 4. Inspection of density-byring plots for individual trees suggested that the data points






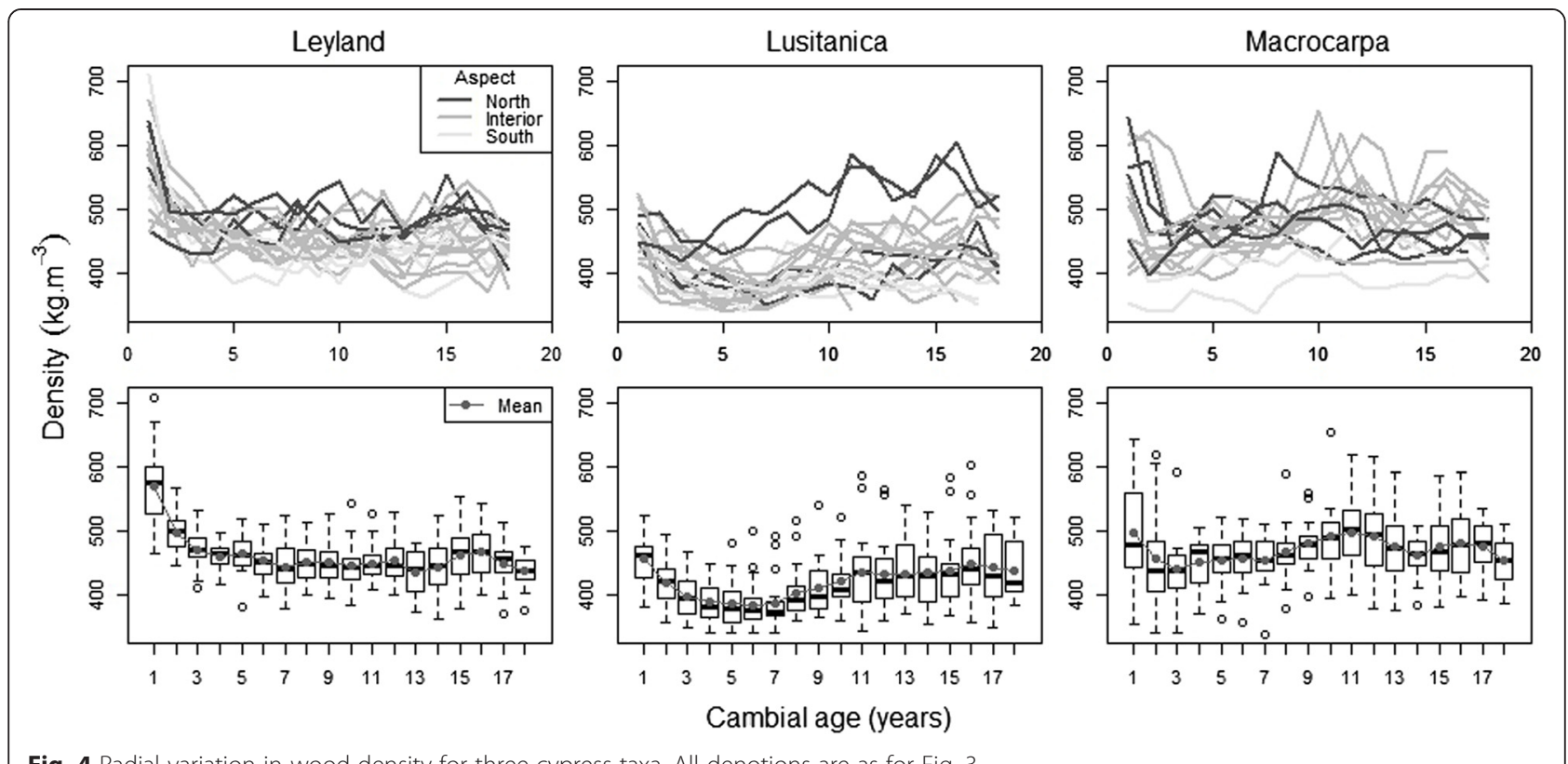

Fig. 4 Radial variation in wood density for three cypress taxa. All denotions are as for Fig. 3

were valid although outliers (which influence mean values) were present (as indicated by the black circles in the figure).

\section{Measured microfibril angle}

Mean MFA followed a declining trend with a relatively steep gradient in the early years of growth (up to about age 10 years), before levelling off (Fig. 5). Overall, mean MFA was lowest for Leyland (with an average of $13.9^{\circ}$ for the period from 12 to 18 years of age) and highest for Macrocarpa (average 18.4 for the same period). Mean MFA of Lusitanica for the same period was $16.5^{\circ}$. Variation about the means was within $\pm 10^{\circ}$ for all trees. Microfibril angle did not appear to be influenced by either aspect or silviculture.

In comparison with Lusitanica, mean MFA of Leyland was significantly lower for all cambial ages up to and including ring 12. In comparison to Macrocarpa, mean MFA of Leyland was not significantly different in the first 4 years of growth, but was significantly lower from
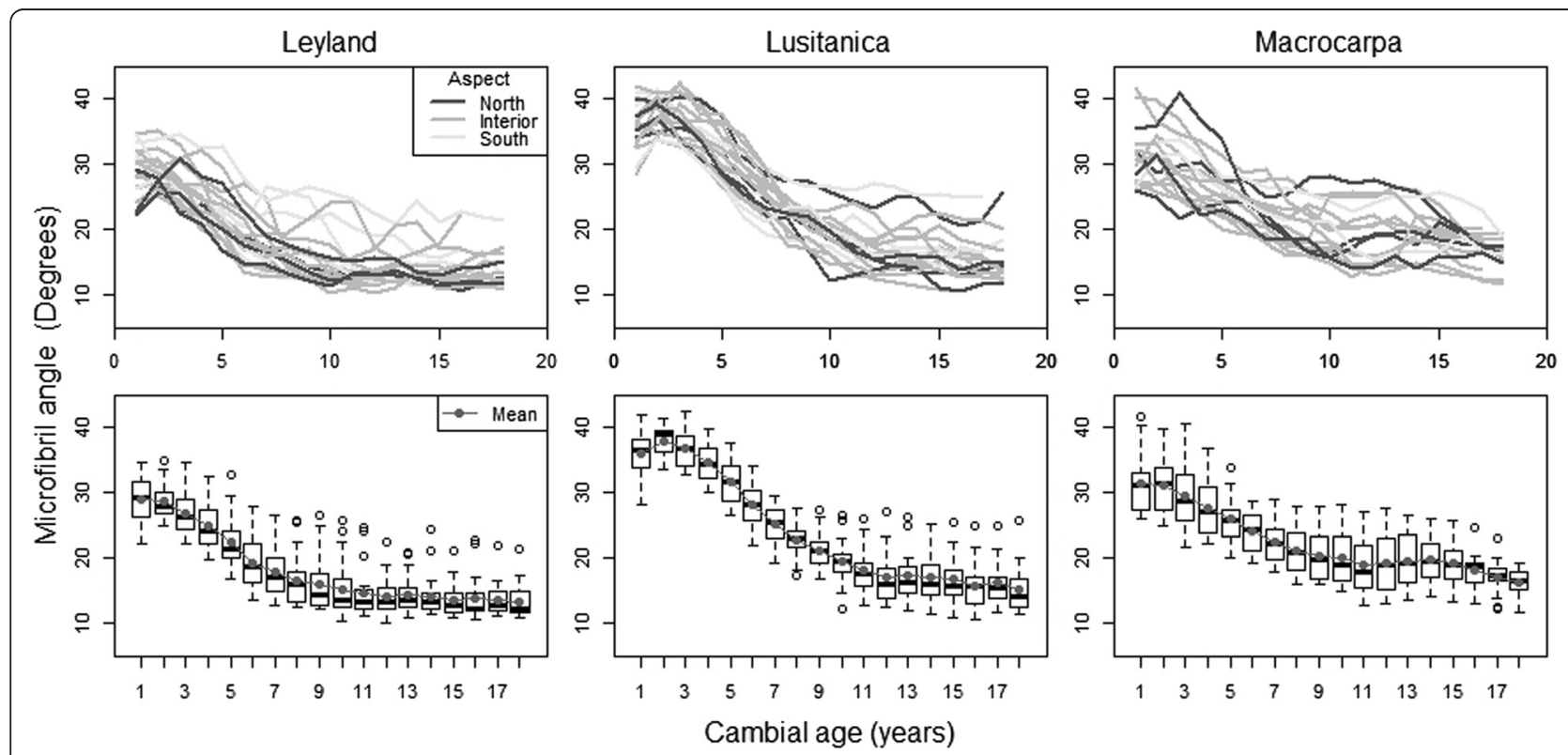

Fig. 5 Radial variation in microfibril angle for three cypress taxa. All denotions are as for Fig. 3 


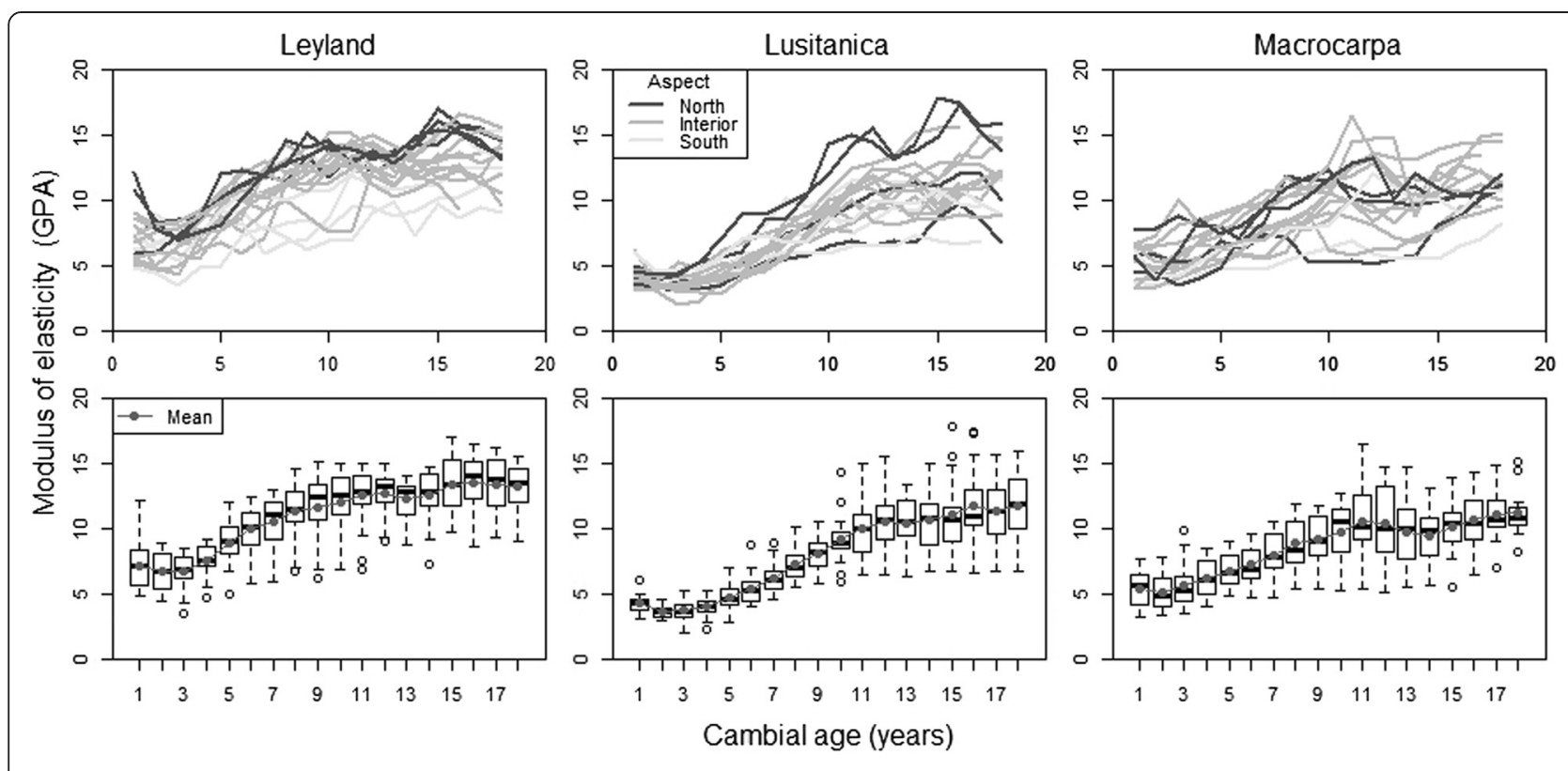

Fig. 6 Radial variation in modulus of elasticity for three cypress taxa. All denotions are as for Fig. 3

age 5 through to 18 years. Mean MFA of Lusitanica was the highest of the three taxa during the early years of growth, being significantly higher than that of Macrocarpa until a cambial age of 7 years (and significantly greater than Leyland until age 12 years).

\section{Measured modulus of elasticity (via Eq. 2)}

Mean MOE generally increased with increasing cambial age, though the reverse trend was noted during the initial 2 to 3 years of growth (Fig. 6). The rate of increase in mean MOE was greater in the earlier half of measurements than in the latter half. Mean MOE for the period from age 11 through to 18 years inclusive was 12.9, 10.9 and 10.4 GPa for Leyland, Lusitanica and Macrocarpa, respectively. At age 18 years, MOE averaged 11-13 GPa; however, trees with a southern aspect were about 1-2 GPa lower. The effect of aspect on MOE appeared to be greater for Leyland than the other two taxa (Fig. 6, top row). Effects due to thinning were minimal (Fig. 6, bottom row).

Mean MOE of Leyland was significantly greater than that of Lusitanica until a cambial age of 16 years and,
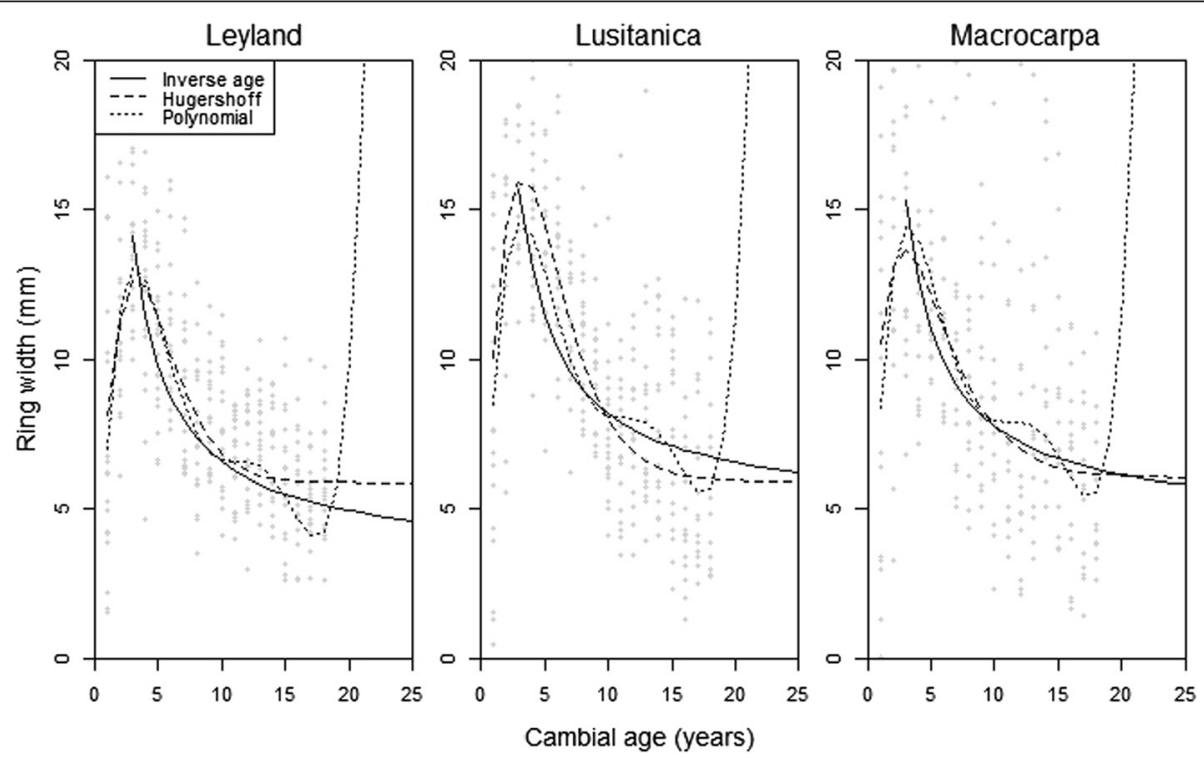

Fig. 7 Models considered for predicting ring width for three cypress taxa 
Table 2 Parameters estimates and fit statistics from fitting the linear mixed-effects model to predict mean ring width

\begin{tabular}{llllll}
\hline Parameter & Value & Std. Error & DF & $t$ value & $p$ value \\
\hline (Intercept) & 3.57 & 0.49 & 802 & 7.35 & 0.000 \\
$A^{-1}$ & 32.2 & 2.0 & 802 & 16.0 & 0.000 \\
Lusitanica & 1.62 & 0.56 & 51 & 2.86 & 0.006 \\
Macrocarpa & 1.21 & 0.59 & 51 & 2.04 & 0.046 \\
South & 2.28 & 0.60 & 501 & 3.83 & 0.000 \\
\hline A cambial age & & & & &
\end{tabular}

with the exception of ring 11, was significantly greater than that of Macrocarpa throughout the 18-year measurement period. Differences in mean MOE between Lusitanica and Macrocarpa were significant only for the first 8 years of growth during which mean MOE of Lusitanica was significantly less than that of Macrocarpa.

\section{Modelled ring width}

Three ring-width models (an inverse transformation of cambial age, Hugershoff curves and a fifth degree polynomial), all augmented by aspect, resulted in similar fit statistics but demonstrated large differences in predictive capability (Fig. 7). The inverse-age model (fitted to rings 3-18 inclusive) demonstrated a gradual decline in ring width with increasing age for predictions beyond ring 18, as would be expected. The nonlinear Hugershoff curves, while providing a better fit in the early years, plateaued early, at about 13 years. The polynomial model provided a reasonable fit to the data until about age 15 years but was impractical for later predictions. Therefore, the final model was a linear mixed-effects model based on the inverse transformation of cambial age, taxon and aspect. Only the southerly aspect was significantly different to the interior aspect. Model parameters are provided in Table 2. Parameter estimates of the autocorrelation and variance structures were 0.591 and -0.142 , respectively. Model performance, as judged by the three goodness-of-fit statistics, was reasonably good in view of the data variability demonstrated in Fig. 3. At the population level, MAPE was $32.4 \%$, RMSE $3.20 \mathrm{~mm}$ and $R^{2}$ was 0.44 .

\section{Modelled wood density}

Radial wood density of the three cypress taxa was modelled by extending the model of Franceschini et al. (2010), with additional variables: taxon, aspect, edge-tree and interaction terms. The model of Franceschini et al. (2010) included cambial age, a square-root transformation of cambial age, a transformation of ring width, and the quotient of cambial age and ring width.

Model parameters of the optimal wood density model, which included all explanatory variables proposed by Franceschini et al. (2010) and additional interactions
Table 3 Parameter estimates and fit statistics from fitting the linear mixed-effects model to predict radial density

\begin{tabular}{llllll}
\hline Parameter & Value & Std. Error & DF & $t$ value & $p$ value \\
\hline (Intercept) & 503 & 25 & 904 & 20.4 & 0.000 \\
Lusitanica & -166 & 31 & 51 & -5.36 & 0.000 \\
Macrocarpa & -187 & 33 & 51 & -5.74 & 0.000 \\
A & 12.2 & 2.7 & 904 & 4.46 & 0.000 \\
A $^{0.5}$ & -95.9 & 15.5 & 904 & -6.17 & 0.000 \\
A/W & -2.96 & 1.43 & 904 & -2.07 & 0.039 \\
1/(1+W W.5 & 480 & 36.9 & 904 & 13.0 & 0.000 \\
North & 24.3 & 8.9 & 51 & 2.75 & 0.008 \\
South & -20.2 & 9.2 & 51 & -2.18 & 0.034 \\
A: Lusitanica & -7.06 & 3.90 & 904 & -1.81 & $0.070^{*}$ \\
A: Macrocarpa & -18.1 & 4.1 & 904 & -4.44 & 0.000 \\
A $^{0.5}$ : Lusitanica & 66.3 & 22.2 & 904 & 2.98 & 0.003 \\
A $^{0.5}$ : Macrocarpa & 125 & 23 & 904 & 5.36 & 0.000 \\
\hline Acambatage $W$ ing & widh & & & &
\end{tabular}

$A$ cambial age, $W$ ring width

${ }^{*}$ not significant

with taxon, are given in Table 3. Parameter estimates of the autocorrelation and variance structures were 0.561 and -0.191, respectively. Edge-tree was not significant as an explanatory variable; however, aspect was highly significant. Trees on the northernmost aspect would be expected to be $44 \mathrm{~kg} \cdot \mathrm{m}^{-3}$ denser than those on the southernmost aspect.

Model performance statistics suggested a relatively strong relationship between actual and estimated mean ring density (Table 4). At the population level for the combined sample, MAPE was $6 \%$, RMSE was $36 \mathrm{~kg} \cdot \mathrm{m}^{-3}$ and $R^{2}$ equalled 0.56 . Overall, the population level model explained about $56 \%$ of the variation in mean density.

Modelled regression lines of mean density, using estimated ring widths from the model parameters presented in Table 2, are shown in Fig. 8 together with $95 \%$ confidence and prediction bands. The confidence intervals (shown in the figure by the shaded grey areas) indicate the likely location of the true population mean and have a precision (width of the interval) of about $\pm 16 \mathrm{~kg} \cdot \mathrm{m}^{-3}$ while precision of the prediction intervals (which include scatter from individual trees) is about $\pm 46 \mathrm{~kg} \cdot \mathrm{m}^{-3}$.

Table 4 Performance statistics of the radial density model, by taxon

\begin{tabular}{llll}
\hline Taxon & MAPE (\%) & RMSE $\left(\mathrm{kg} \cdot \mathrm{m}^{-3}\right)$ & $R^{2}$ \\
\hline Leyland & 5.1 & 30 & 0.56 \\
Lusitanica & 7.0 & 38 & 0.46 \\
Macrocarpa & 6.5 & 41 & 0.42 \\
All & 6.1 & 36 & 0.56 \\
\hline
\end{tabular}

MAPE mean absolute percentage error, RMSE root mean square error, $R^{2}$ coefficient of determination 



Fig. 8 Prediction of radial density for three cypress taxa. The regression line is shown as a solid line, the $95 \%$ confidence bands for the regression line are shown as dashed lines with the confidence interval shaded grey and the $95 \%$ prediction bands are shown as dotted lines

\section{Modelled microfibril angle}

A linear mixed-effects polynomial model based on cambial age provided good fit statistics, but due to its symmetric nature, was not reliable for forecasting MFA beyond the sample interval (1-18 years). Improved forecasting was however obtained with an alternative model, based on an exponential equation and similar in form to the MFA model of Cortini et al. (2014). The response variable (MFA) was log-transformed as were two explanatory variables (cambial age and distance from pith), which were transformed following visualisation of the data plots. Taxon was highly significant as an explanatory variable. However, unlike the density model, interaction terms with taxon were not significant, but interaction between ring width and the logarithmic transform of age was highly significant. Aspect and edge-tree were not significant. Parameter estimates of the final linear model are given in Table 5. Parameter

Table 5 Parameter estimates and fit statistics from fitting the linear mixed-effects model to predict radial logarithmic microfibril angle, In(MFA)

\begin{tabular}{llllll}
\hline Parameter & Value & Std. Error & DF & $t$ value & $p$ value \\
\hline (Intercept) & 3.50 & 0.14 & 799 & 24.9 & 0.000 \\
Lusitanica & 0.216 & 0.046 & 52 & 4.66 & 0.000 \\
Macrocarpa & 0.146 & 0.047 & 52 & 3.12 & 0.003 \\
In(A) & -0.597 & 0.057 & 799 & -10.4 & 0.000 \\
W & -0.010 & 0.004 & 799 & -2.71 & 0.007 \\
$\ln (\mathrm{X})$ & 0.136 & 0.053 & 799 & 2.55 & 0.011 \\
$\operatorname{In}(\mathrm{A}): \mathrm{W}$ & 0.00764 & 0.00169 & 799 & 4.52 & 0.000 \\
\hline A Cambin
\end{tabular}

$A$ cambial age, $W$ ring width, $X$ distance from pith estimates for the autocorrelation and variance structures were 0.905 and 0.104 , respectively.

Performance statistics comparing actual with predicted MFA demonstrated a strong relationship between actual and estimated mean microfibril angle (Table 6). At the population level for all taxa, MAPE was about $16 \%$, RMSE $3.7^{\circ}$, and $R^{2}$ equalled 0.69 .

The modelled regression lines of mean microfibril angle are shown in Fig. 9 together with 95 \% confidence and prediction bands. Due to the logarithmic transform of the response variable, a bias correction factor (Snowdon 1991) was calculated for each taxon $(0.98,0.99$ and 1.03 for Leyland, Lusitanica and Macrocarpa, respectively) and applied when calculating predicted MFA. The confidence intervals shown in the figure have a precision of about $\pm 2.0^{\circ}$ while precision of the prediction intervals is about $\pm 3.8^{\circ}$.

\section{Modelled modulus of elasticity}

Linear and nonlinear mixed effects models were considered when developing the MOE models. Nonlinear models for each taxon were based on the Mitscherlich equation (Briggs 1925), augmented by aspect. Final

Table 6 Performance statistics of the radial microfibril angle model, by taxon

\begin{tabular}{llll}
\hline Taxon & MAPE $(\%)$ & RMSE $\left(^{\circ}\right)$ & $R^{2}$ \\
\hline Leyland & 15.3 & 3.7 & 0.64 \\
Lusitanica & 16.0 & 3.7 & 0.77 \\
Macrocarpa & 14.4 & 3.7 & 0.63 \\
All & 15.6 & 3.7 & 0.69 \\
\hline
\end{tabular}

MAPE mean absolute percentage error, RMSE root mean square error, $R^{2}$ coefficient of determination 

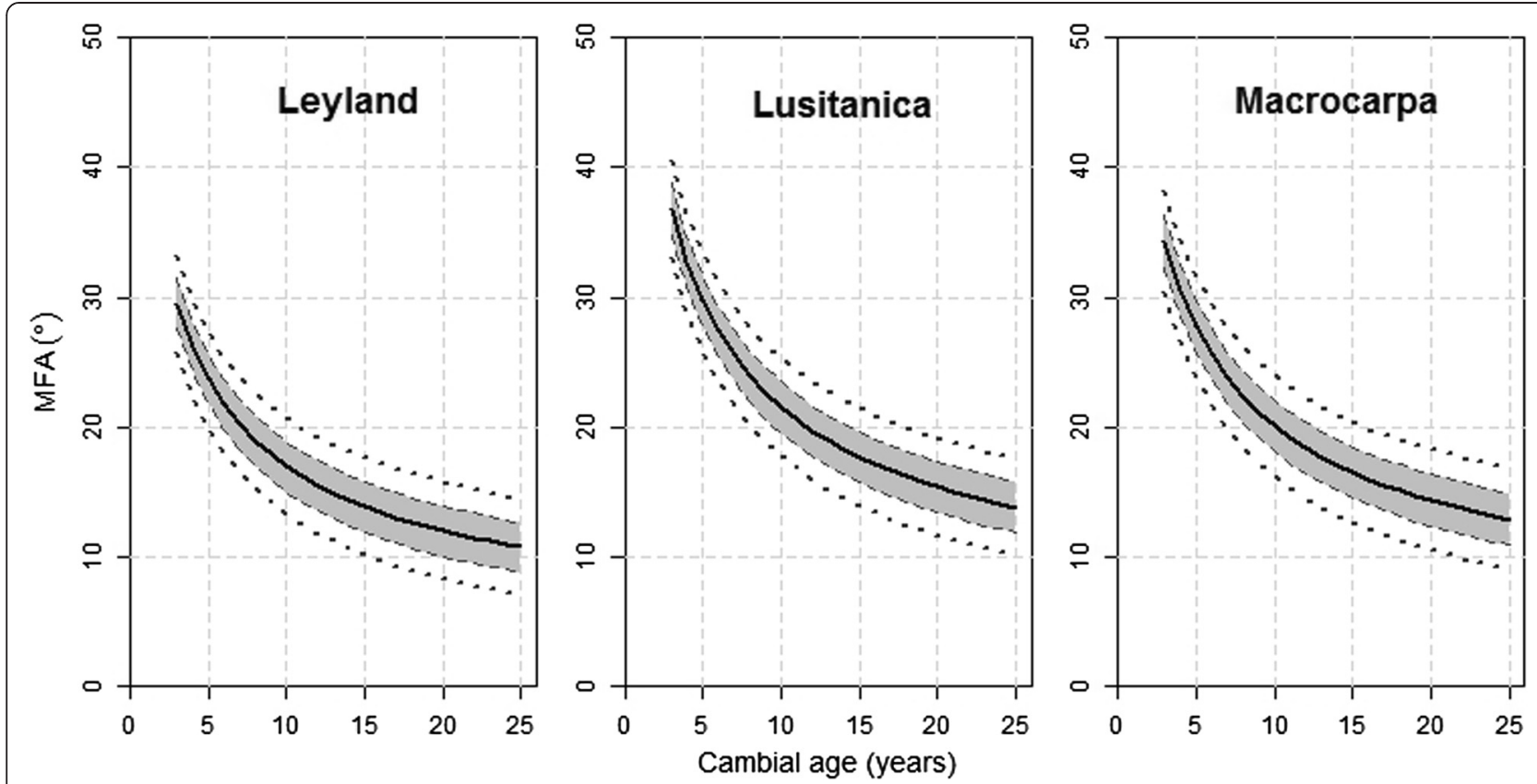

Fig. 9 Prediction of microfibril angle for three cypress taxa. The regression line is shown as a solid line, the $95 \%$ confidence bands for the regression line are shown as dashed lines with the confidence interval shaded grey and the $95 \%$ prediction bands are shown as dotted lines

models, with better fit statistics, were of linear form. Explanatory variables comprised taxon, ring width, the logarithmic transform of cambial age and aspect. The southern aspect was significantly different to the intermediary aspect, but the northern aspect was not. An interaction term with ring width was also highly significant for the southern aspect only. Therefore, a new variable that only distinguished the southern aspect was introduced in the model (Table 7). Parameter estimates for the autocorrelation and variance structures were 0.834 and 0.133 , respectively. Performance statistics, which suggest a good fit between actual and estimated MOE, are provided in Table 8.

The modelled regression lines of mean modulus of elasticity are shown in Fig. 10 together with $95 \%$ confidence and prediction bands. The confidence intervals

Table 7 Parameter estimates and fit statistics from fitting the linear mixed-effects model to predict radial modulus of elasticity (MOE)

\begin{tabular}{llllll}
\hline Parameter & Value & Std. Error & DF & $t$ value & $p$ value \\
\hline (Intercept) & 6.34 & 0.49 & 800 & 13.0 & 0.000 \\
Lusitanica & -2.54 & 0.37 & 51 & -6.87 & 0.000 \\
Macrocarpa & -1.94 & 0.39 & 51 & -4.98 & 0.000 \\
Southern & -2.16 & 0.51 & 51 & -4.24 & 0.000 \\
In(A) & 2.91 & 0.17 & 800 & 16.8 & 0.000 \\
W & -0.170 & 0.014 & 800 & -11.8 & 0.000 \\
W: Southern & 0.102 & 0.027 & 800 & 3.83 & 0.000 \\
\hline
\end{tabular}

$A$ cambial age, $W$ ring width have a precision of about $\pm 0.7 \mathrm{GPa}$, while precision of the prediction intervals is about $\pm 1.4 \mathrm{GPa}$.

\section{Forecasts of earliest age for production of timber of specific MOE}

The steps outlined under 'Application of Models' were followed to estimate the earliest possible ages for producing $100 \times 50 \times 2.0$ and $150 \times 50 \times 2.0$ timber (width $(\mathrm{mm})$, thickness $(\mathrm{mm})$, length $(\mathrm{m}))$ timber of 6 and $8 \mathrm{GPa}$. One minor modification to the procedure was required due to the ring-width models being valid for cambial age greater than 2 years. The modification entailed adding the sum of the actual mean ring widths of the first two rings (totalling $18 \mathrm{~mm}$ for Leyland and $24 \mathrm{~mm}$ for Lusitanica and Macrocarpa) to the cumulative sum obtained from the ring-width models.

With this procedure, the minimum age for producing $100 \mathrm{~mm} \times 50 \mathrm{~mm} \times 2.0 \mathrm{~m} 6 \mathrm{GPa}$ timber from Leyland stands was estimated to be 22 years whereas that for Lusitanica was 32 years and for Macrocarpa 29 years. At

Table 8 Performance statistics of the radial modulus of elasticity model, by taxon

\begin{tabular}{llll}
\hline Taxon & MAPE (\%) & RMSE (GPa) & $R^{2}$ \\
\hline Leyland & 13.3 & 1.66 & 0.65 \\
Lusitanica & 19.8 & 1.85 & 0.74 \\
Macrocarpa & 17.2 & 1.71 & 0.59 \\
All & 16.6 & 1.74 & 0.66 \\
\hline
\end{tabular}

MAPE mean absolute percentage error, RMSE root mean square error, $R^{2}$ coefficient of determination 

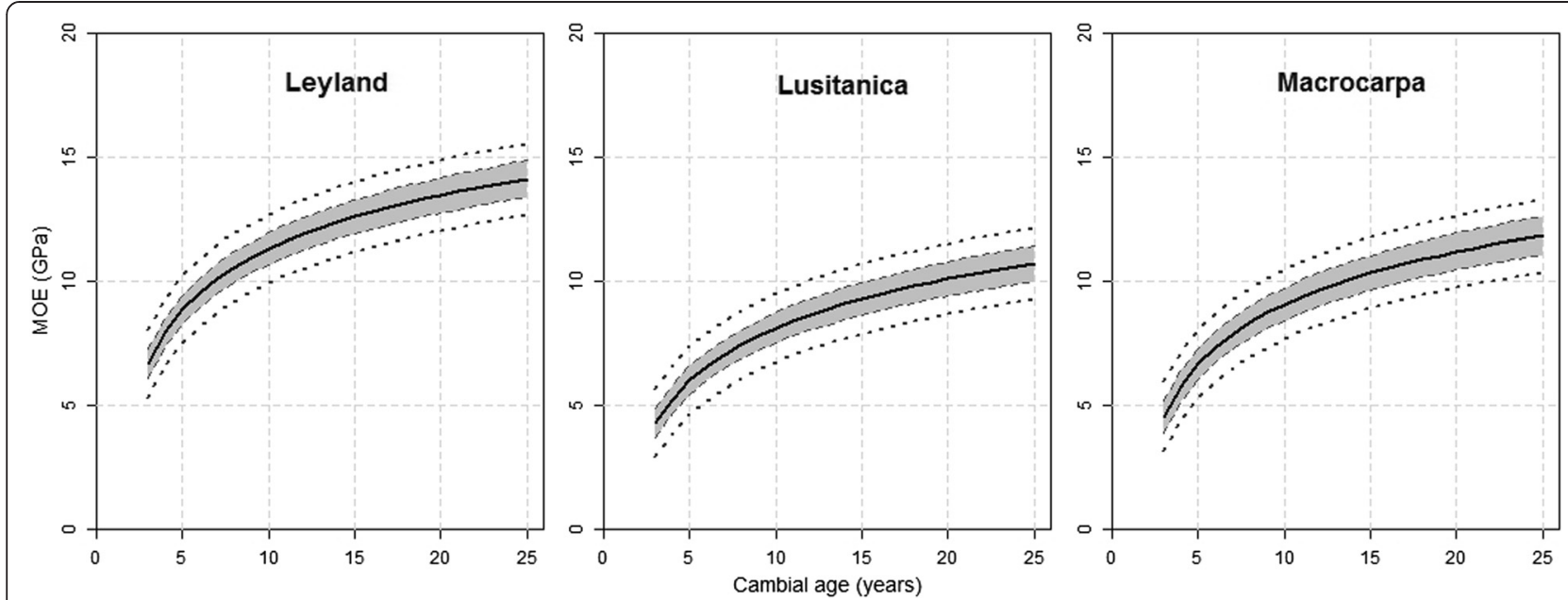

Fig. 10 Prediction of modulus of elasticity for three cypress taxa. The regression line is shown as a solid line, the $95 \%$ confidence bands for the regression line are shown as dashed lines with the confidence interval shaded grey and the $95 \%$ prediction bands are shown as dotted lines

25 years, wider timber $(150 \mathrm{~mm})$ can be produced from Leyland, and by 30 years, production of $8 \mathrm{GPa}$ timber is forecast to be possible. Age forecasts for 6 and $8 \mathrm{GPa}$ products are summarised in Table 9. Overall, forecasted ages for production of strength-grade timber were greatest for Lusitanica and least for Leyland.

\section{Discussion}

All results presented here were based on trees growing in row-plots. Though the row-plot design results in a greater proportion of edge trees than other plot designs, the edge-tree effect was not significant in any of the wood property models. Aspect, on the other hand, was highly significant in models predicting wood density. Trees on the northernmost aspect (warmest aspect with more sunshine in the Southern hemisphere) had greater wood density, amounting to about $44 \mathrm{~kg} \cdot \mathrm{m}^{-3}$ more than those on the southernmost aspect. As suggested by van der Maaten (2012), these differences may relate to the differing levels of irradiation between aspects. On this basis, it would be expected that a similar plot design in the Northern hemisphere would result in trees with a southern aspect having greater wood density.

Overall, wood density gradients of the three cypress taxa were relatively flat, as suggested by Brailsford (1999). At age 25 years, mean density of the three taxa, using the models whose parameters are given in Table 3, is estimated to be 461,441 and $437 \mathrm{~kg} \cdot \mathrm{m}^{-3}$, for Leyland, Lusitanica and Macrocarpa, respectively. However, with large variation due to individual trees, the $95 \%$ prediction interval suggests that density at age 25 years could be as low as 410,389 and $385 \mathrm{~kg} \cdot \mathrm{m}^{-3}$ or as high as 511 , 492 and $489 \mathrm{~kg} \cdot \mathrm{m}^{-3}$ for trees of the three taxa, respectively. As all values are lower than the $540 \mathrm{~kg} \cdot \mathrm{m}^{-3}$ threshold indicating low-density wood, it can be expected that the timber of these cypress taxa will dent easily when depressed.

Radial patterns of microfibril angle of the three cypress taxa were similar to those of other conifers, with the highest angles occurring in the first five growth rings (McMillin 1973, Zhang et al. 2007), and like MFA of Pinus radiata (Moore et al. 2014), the cypress taxa had comparable and low MFA values (Donaldson 1992). Mean MFA of the first five growth rings was $25^{\circ}, 45^{\circ}$ and $29^{\circ}$ for Leyland, Lusitanica and Macrocarpa, respectively, while at age 25 years, mean MFA was estimated to be $11^{\circ}, 14^{\circ}$ and $13^{\circ}$ for the three taxa, respectively.

Mean modulus of elasticity of Leyland was greater than that of either Lusitanica or Macrocarpa for the majority of the tree rings analysed here (up to and including a cambial age of 18 years). At age 18 years, mean MOE of Leyland was $13 \mathrm{GPa}$, about $2 \mathrm{GPa}$ greater than

Table 9 Forecasts of the earliest age (years) at which product specifications can be met

\begin{tabular}{lllll}
\hline Taxon & \multicolumn{4}{l}{ Product (strength-grade $\times$ width) } \\
\cline { 2 - 5 } & $6 \mathrm{GPa} \times 100 \mathrm{~mm}$ & $6 \mathrm{GPa} \times 150 \mathrm{~mm}$ & $8 \mathrm{GPa} \times 100 \mathrm{~mm}$ & $8 \mathrm{GPa} \times 150 \mathrm{~mm}$ \\
\hline Leyland & 22 & 25 & 30 & 32 \\
Lusitanica & 32 & 33 & $>35$ & $>35$ \\
Macrocarpa & 29 & 31 & $>35$ & $>35$ \\
\hline
\end{tabular}

Products in this example forecast are $50 \mathrm{~mm}$ thick and $2.0 \mathrm{~m}$ long 
that of the other two taxa. At age 25 years, predicted mean MOE of the three taxa was 14,11 and $12 \mathrm{GPa}$, respectively, while $\mathrm{MOE}$ of the lower (95\%) prediction bands was 13, 9 and $10 \mathrm{GPa}$, respectively. Thus, at age 25 years, it would be expected that products derived from stands of Lusitanica and Macrocarpa would fail to meet the engineering grade criteria of $10.5 \mathrm{GPa}$ and would attain 6 and $8 \mathrm{GPa}$ strength grades only if sufficient growth had occurred.

Forecasts of the age at which specific product density or MFA is attained can be made following the steps outlined in 'Application of Models'. However, while forecasts using the above wood property models address wood quality and form, other degrading features such as knots, warp on drying and internal checking need consideration. For Lusitanica and Macrocarpa, Low et al. (2005) reported problems with warp on drying for the former taxon and problems with internal checking for the latter. However, the Leyland hybrid was reported as having good performance in terms of both appearance and structural products. In general, wood properties can vary for trees growing under different conditions; therefore, if growth rates differ to those presented here, forecasts will need to be revised to match the growing conditions.

\section{Conclusions}

Shorter rotations appear to be feasible for Leyland, with the production of $6 \mathrm{GPa}$ timber being possible from the outer $\log$ zones from age 22 years. However, benefits of shortened rotations for either Lusitanica or Macrocarpa are questionable. With other studies demonstrating good performance of Leyland timber for both appearances and structural products, this hybrid cypress taxon is a suitable candidate for increased production forestry from exotic species in New Zealand.

Characterisation of radial variation in wood properties is an important step in forecasting not only harvesting ages but also potential product quality. Various product scenarios, of both existing and new products, can be evaluated using methods and models developed here.

\section{Competing interests}

The authors declare that they have no competing interests.

\section{Authors' contributions}

CLT provided statistical design, analysis and manuscript writing. CBL contributed initial project design, database construction and consolidation and manuscript writing. HMM controlled the logging operation and tree selection process and provided impetus for this study, including its write-up. LDG facilitated the cypress trial and provided input to key concepts culminating in this manuscript. All authors read and approved the final manuscript.

\section{Acknowledgements}

The authors would like to thank Mark Miller and Kane Fleet for extracting increment cores; Robert Evans, Sarah King, Sharee Harper, Roxanne Luff and the Silviscan ${ }^{\oplus}$ team for processing the cores; Neena Ranchod-Shaw for estimating ring boundaries from Silviscan ${ }^{\circledast}$ data; and Heidi Dungey for constructive comments on early drafts.

\section{Author details}

${ }^{1}$ Scion, Private Bag 3020, Rotorua 3046, New Zealand. ${ }^{2}$ Centralis Limited, 3 Ferndale Drive, Waikanae 5036, New Zealand. ${ }^{3} 412$ No. 1 Road, RD2, Te Puke 3182, New Zealand.

Received: 19 November 2014 Accepted: 27 September 2015

Published online: 16 November 2015

\section{References}

Akaike, H. (1974). A new look at the statistical model identification. IEEE Transactions on Automatic Control, 19(6), 716-723. doi:10.1109/TAC.1974.1100705.

Auty, D, Gardiner, BA, Achim, A, Moore, JR, \& Cameron, AD. (2013). Models for predicting microfibril angle variation in Scots pine. Annals of Forest Science, 70, 209-218

Bošela, M, Kulla, L, \& Marušák, R. (2011). Detrending ability of several regression equations in tree-ring research: a case study based on tree-ring data of Norway spruce (Picea abies [L.]). Journal of Forest Science, 57, 491-499.

Bouriaud, O, Breda, N, Le Moguedec, G, \& Nepveu, G. (2004). Modelling variability of wood density in beech as affected by ring age, radial growth and climate. Trees, 18, 264-276.

Brailsford, S. (1999). The cypress growers' handbook. Christchurch, New Zealand: Brailsford's Forest Management Ltd.

Briggs, GE. (1925). Plant yield and the intensity of external factors-Mitscherlich's 'Wirkungsgesetz'. Annals of Botany, 39, 475-502.

Chappell, PR (2013). The climate and weather of Bay of Plenty. (3rd edition). [NIWA Science and Technology Series, Number 62]. Wellington, New Zealand: National Institute of Water and Atmospheric Research.

Cortini, F, Groot, A, Tong, Q, \& Duchesne, I. (2014). Ring-level models for predicting wood and fibre properties of Abies balsamea. Wood Science Technology, 48, 1181-1196.

Donaldson, LA. (1987). S3 Lignin concentration in radiata pine tracheids. Wood Science Technology, 21, 227-234.

Donaldson, LA. (1992). Within- and between-tree variation in microfibril angle in Pinus radiata. New Zealand Journal of Forestry Science, 22, 77-86.

Donaldson, L. (2008). Microfibril angle: measurement, variation and relationships-a review. IAWA Journal, 29(4), 345-338.

Evans, R, Downes, GM, Menz, DNJ, \& Stringer, SL. (1995). Rapid measurement of variation in tracheid transverse dimensions in a radiata pine tree. Appita Journal, 48(2), 134-138.

Evans, R, \& llic, J. (2001). Rapid prediction of wood stiffness from microfibril angle and density. Forest Products Journal, 51, 53-57.

Evans, R. (2006). Wood stiffness by X-ray diffractometry. In DD Stokke \& LH Groom (Eds.), Characterization of the cellulosic cell wall. Proceedings of a Workshop Cosponsored by the USDA Forest Service, Southern Research Station; the Society of Wood Science and Technology; and lowa State University, August 25-27, 2003, Grand Lake, Colorado. (pp. 138-146). Ames, IA, USA: Blackwell Publishing.

Fang, K, Gou, X, Peters, K, Li, J, \& Zhang, F. (2010). Removing biological trends from tree-ring series: testing modified Hugershoff curves. Tree-Ring Research, $66,51-59$.

Fang, S, Wenzhong, Y, \& Ye, T. (2006). Clonal and within-tree variation in microfibril angle in 10 poplar clones. New Forests, 31, 373-383.

Filipescu, CN, Lowell, EC, Koppenaal, R, \& Mitchella, AK. (2014). Modeling regional and climatic variation of wood density and ring width in intensively managed Douglas-fir. Canadian Journal of Forest Research, 44(3), 220-229. doi:10.1139/cifr-2013-0275.

Franceschini, T, Bontemps, J-D, Gelhaye, P, Rittie, D, Herve, J-C, Gegout, J-C, \& Leban, J-M. (2010). Decreasing trend and fluctuations in the mean ring density of Norway spruce through the twentieth century. Annals of Forest Science, 67(816), 1-10. doi:10.1051/forest/2010055.

Gaunt, D. (1998). If you are not winning, change the rules. Wood Processing Newsletter 23, (Sawmilling 3-5). Rotorua, New Zealand: Forest Research Institute.

Haslett, AN. (1986). Properties and utilisation of exotic speciality timbers grown in New Zealand. Part III: Cypresses Chamaecyparis lawsoniana (A. Murr.) Parl. x Cupressocyparis leylandii (Jacks et Dall.) Dall. Cupressus lusitanica Mill. Cupressus macrocarpa Hartw (FRI Bulletin No. 119). Rotorua, New Zealand: Forest Research Institute. 
Hugershoff, R. (1936). Die mathematischen Hilfsmittel des Kulturingenieurs und Biologen (Vol. 2). Dresden: Herleitung von gesetzmäßigen Zusammenhängen. als Manuskript veröffentlicht.

Ivković, M, Gapare, W, Wu, H, Espinoza, S, \& Rozenberg, P. (2013). Influence of cambial age and climate on ring width and wood density in Pinus radiata families. Annals of Forest Science, 70, 525-534. doi:10.1007/s13595-013-0290-z.

Jordan, L, Daniels, RF, Clark, A, \& He, R. (2005). Multilevel nonlinear mixed-effects models for the modelling of earlywood and latewood microfibril angle. Forest Science, 51, 357-371.

Jyske, T, Makinen, H, \& Saranpaa, P. (2008). Wood density within Norway spruce stems. Silva Fennica, 42, 439-455.

Laird, NM, \& Ware, JH. (1982). Random effects models for longitudinal data. Biometrics, 38, 963-974. doi:10.2307/2529876.

Lasserre, J-P, Mason, EG, Watt, MS, \& Moore, JR. (2009). Influence of initial planting spacing and genotype on microfibril angle, wood density, fibre properties and modulus of elasticity in Pinus radiata D. Don corewood. Forest Ecology and Management, 258(9), 1924-1931.

Low, CB, McKenzie, HM, Shelbourne, CJA, \& Gea, LD. (2005). Sawn timber and wood properties of 21-year-old Cupressus Lusitanica, C. Macrocarpa, and Chamaecyparis Nootkatensis x C. Macrocarpa hybrids. Part 1: sawn timber performance. New Zealand Journal of Forestry Science, 35(1), 91-113.

Lundgren, C. (2004). Microfibril angle and density patterns of fertilized and irrigated Norway spruce. Silva Fennica, 38(1), 107-117.

McKinley, RB, Shelbourne, CJA, Harris, JM, \& Young, GD. (2000). Variation in whole-tree basic wood density for a range of plantation species grown in New Zealand. New Zealand Journal of Forestry Science, 30(3), 436-446.

McMillin, CW. (1973). Fibril angle of loblolly pine wood as related to specific gravity, growth rate and distance from the pith. Wood Science Technology, 7, 251-255.

Malimbwi, RE, Persson, A, Iddi, S, Chamshama, SAO, \& Mwihomeke, ST. (1992). Effects of spacing on yield and some wood properties of Cupressus lusitanica at Rongai, Northern Tanzania. Forest, 65, 73-82.

Miller, JT, \& Knowles, FB. (1996). Introduced forest trees in New Zealand: recognition, role and seed source. 9. The cypresses (NZFRI Bulletin No 124(9)). Rotorua, New Zealand: Forest Research Institute.

Moore, J, Cown, DJ, McKinley, RB (2014). Modelling microfibril angle variation in New Zealand-grown radiata pine. New Zealand Journal of Forestry Science 44:25. doi:10.1186/s40490-014-0025-4

Peschel, W. (1938). Die mathematischen methoden zur herleitung der wachstumsgesetze von baum und bestand und die ergebnisse ihrer an wendung. Tharandter forstliches Jahrbuch, 89(3/4), 169-247.

Piispanen, R, Heinonen, J, Valkonen, S, Mäkinen, H, Lundqvist, S-O, \& Saranpää, P. (2014). Wood density of Norway spruce in uneven-aged stands. Canadian Journal of Forest Research, 44, 136-144.

Pinheiro, J. (2002). Model building using covariates in nonlinear mixed-effects models. Journal de la société française de statistique, 143, 79-101.

Pinheiro, J, Bates, D, DebRoy, S, Sarkar, D, \& the R Development Core Team. (2013). nlme: Linear and nonlinear mixed effects models. (R package version 3.1-111).

R Core Team. (2013). R: a language and environment for statistical computing. Vienna, Austria: R Foundation for Statistical Computing.

Snowdon, P. (1991). A ratio estimator for bias correction in logarithmic regressions. Canadian Journal of Forest Research, 21, 720-724.

Standards New Zealand. (1993). NZS 3603:1993 timber structures standard. Wellington: Wright \& Carman Ltd.

van der Maaten, E. (2012). Climate sensitivity of radial growth in European beech (Fagus sylvatica L.) at different aspects in southwestern Germany. Trees, 26, 777-788.

Vikram, V, Cherry, ML, Briggs, D, Cress, DW, Evans, R, \& Howe, GT. (2011). Stiffness of Douglas-fir lumber: effects of wood properties and genetics. Canadian Journal of Forest Research, 41, 1160-1173.

Vincent, TG, \& Dunstan, JS. (1989). Register of commercial seedlots issued by the New Zealand Forest Service. FRI Bulletin No. 144. Rotorua, New Zealand: Forest Research Institute.

Walker, JCF, \& Butterfield, BG (1995). The importance of microfibril angle for the processing industries. New Zealand Forestry, 40(3), 34-40.

Watt, MS, Clinton, PW, Coker, G, Davis, MR, Simcock, R, Parfitt, RL, \& Dando, J. (2008). Modelling the influence of environment and stand characteristics on basic density and modulus of elasticity for young Pinus radiata and Cupressus lusitanica. Forest Ecology and Management, 255(3/4), 1023-1033.
Wimmer, R, \& Downes, GM. (2003). Temporal variation of the ring width-wood density relationship in Norway spruce grown under two levels of anthropogenic disturbance. IAWA Journal, 24(1), 53-61.

Yang, JL, \& Evans, R. (2006). Prediction of MOE of eucalypt wood from microfibril angle and density. Holz als Roh und Werkstoff, 61, 449-452.

Zhang, B, Fei, B-H, Yu, Y, \& Zhao, R-J. (2007). Microfibril angle variability in Masson pine (Pinus massoniana Lamb.) using $X$-ray diffraction. Forestry Studies China, 9, 33-38.

Zuur, AF, leno, EN, Walker, NJ, Saveliev, AA, Smith, GM (2009). Mixed effects models and extensions in ecology with R. Statistics for biology and health. New York: springer-Verlag.

\section{Submit your manuscript to a SpringerOpen ${ }^{\odot}$ journal and benefit from:}

- Convenient online submission

- Rigorous peer review

- Immediate publication on acceptance

- Open access: articles freely available online

- High visibility within the field

- Retaining the copyright to your article

Submit your next manuscript at $>$ springeropen.com 